\title{
Stinging and Venomous Caterpillars of the Southeast ${ }^{1}$
}

\author{
Rebecca Perry and Adam Dale ${ }^{2}$
}

A previous version of this fact sheet is included in SP134: Pests in and around the Florida Home, which is available from the IFAS Extension Bookstore (http://ifasbooks.ifas. ufl.edu/p-154-pests-in-and-around-the-florida-home.aspx).

\section{Introduction}

Wasp and bee stings are familiar to most people, but some might be surprised to learn that several caterpillars can also sting. Some learn by painful experience, having encountered or handled a stinging caterpillar. Unlike wasps and bees with stingers, stinging caterpillars have urticating hairs, which are barbed hairs that easily break off the caterpillar's body if the caterpillar is brushed against and can embed in a person or animal's skin, where they cause sudden or gradually building pain. The severity of a sting varies based on the person and number of spines embedded in the skin. Many stinging caterpillars also release a toxin on contact with the spines, which may be a health concern for some people. The caterpillars discussed in this document are found throughout the southeastern United States.

\section{Saddleback Caterpillar, Acharia stimulea (Clemens) (Lepidoptera: Limacodidae)}

\section{Identification}

The saddleback caterpillar is brown on the front and hind ends. The middle of the caterpillar is green with a brown oval that is usually bordered with white. This coloration pattern resembles a green "saddle blanket" and brown "saddle," hence the common name. The coloring can provide camouflage from predators or people. Fully grown caterpillars are stout-bodied, reaching about $2 \mathrm{~cm}$ long. Most stinging hairs originate on the pairs of protruding fleshy structures toward the front and hind ends of the body. There is also a row of smaller stinging organs on each side (Figure 1). The caterpillar's coloration is a form of defense referred to as aposematism, a visual color warning to predators of its toxicity.

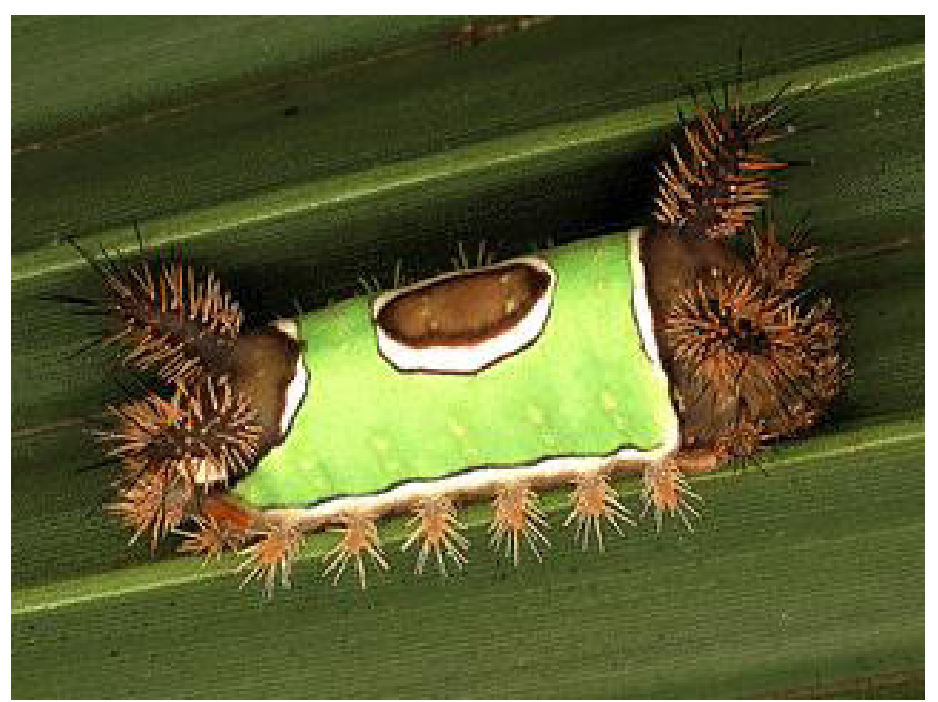

Figure 1. Saddleback caterpillar, Acharia stimulea.

Credits: Don Hall, UF/IFAS

1. This document is SP107, one of a series of the Entomology and Nematology Department, UF/IFAS Extension. Originally published in January 1992 as Stinging and Venomous Caterpillars, an insect ID sheet available as part of a set from the UF/IFAS Extension Bookstore. Revised October 2013 by D.E. Short, professor; D.H. Habeck, professor; and J.L. Castner, scientific photographer. Reviewed and revised June 2018 by Rebecca Perry anhd Adam Dale. Visit the EDIS website at http://edis.ifas.ufl.edu.

2. Rebecca Perry, graduate student; and Adam Dale, assistant professor and Extension specialist; Department of Entomology and Nematology, UF/IFAS Extension, Gainesville, 32611.

The Institute of Food and Agricultural Sciences (IFAS) is an Equal Opportunity Institution authorized to provide research, educational information and other services

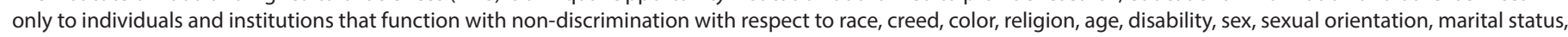

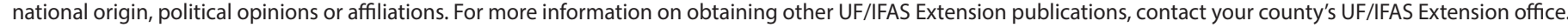
U.S. Department of Agriculture, UF/IFAS Extension Service, University of Florida, IFAS, Florida A \& M University Cooperative Extension Program, and Boards of County Commissioners Cooperating. Nick T. Place, dean for UF/IFAS Extension. 


\section{Hosts}

Saddleback caterpillars feed on a wide variety of plants, including maples (Acer spp.), hibiscus (Hibiscus spp.), and crape myrtle (Lagerstroemia spp.).

\section{Health Concerns and Symptoms}

Saddleback caterpillar spines are hollow and can easily break off, embedding deeply into skin. An intense burning, inflammation, and red blanching may occur around the affected area. The spines contain a toxin that can cause tissue damage and may cause acute urticaria, or rashes of round, red welts that swell and itch intensely. Medical attention may be necessary.

For more information see: http://edis.ifas.ufl.edu/in923.

\section{Puss Caterpillar (Larva), Southern Flannel Moth (adult) Scientific Name: Megalopyge opercularis (J.E. Smith) (Lepidoptera: Megalopygidae)}

The larva is convex and stout-bodied, almost 1 inch long when mature, and completely covered with gray to brown hairs (Figure 2). Under the soft hairs are stiff spines that are attached to poison glands. When touched, these poisonous spines break off in the skin and cause severe pain. Puss caterpillars feed on a variety of broadleaf trees and shrubs, and are most often found on oaks and citrus. In Florida there are two generations a year, one in spring and the other in fall. Natural enemies keep these caterpillars at low numbers during most years, but they periodically become numerous.

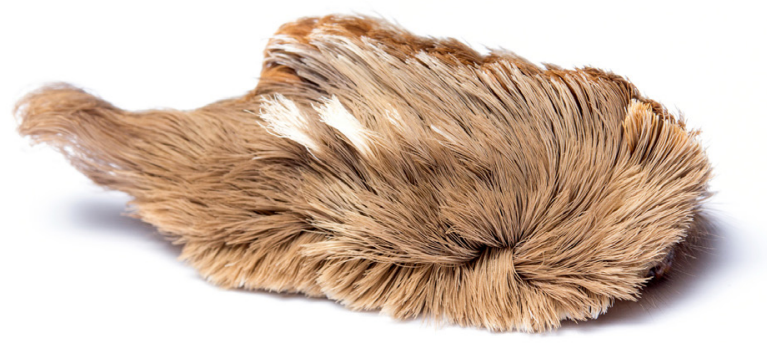

(C) MATT BERTONE 2013

Figure 2. Puss caterpillar, Megalopyge opercularis. Credits: Matt Bertone, North Carolina State University

\section{Identification}

The puss caterpillar is stout-bodied, approximately $2.5 \mathrm{~cm}$ long, and completely covered with gray or pale brown hairs (Figure 2). Its head, with chewing mouthparts, is concealed beneath the dense, long hairs (Figure 3). The rear of the caterpillar tapers to a tail that extends beyond the body. Early life stages of caterpillars are called instars. Early instar puss caterpillars have significantly fewer hairs than later instars. Puss caterpillars are often mistaken as safe to handle due to their soft furry appearance. In Florida, there are two generations per year, one in spring and the other in fall.

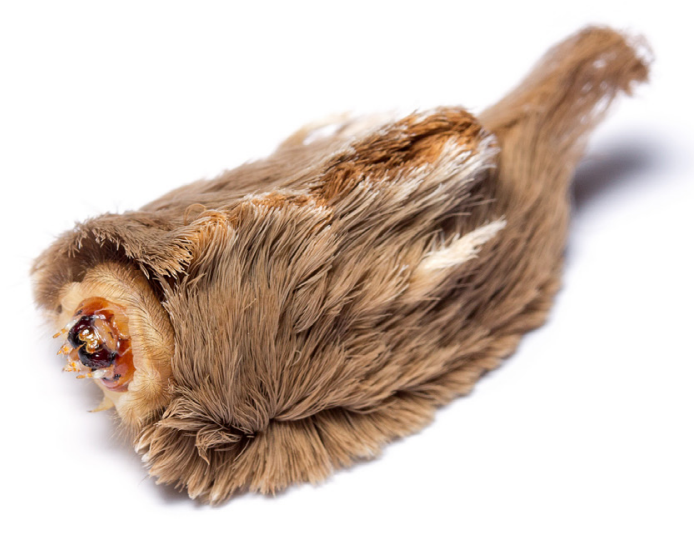

(c) MATT BERTONE 2013

Figure 3. Puss caterpillar with head and mouthparts exposed. Credits: Matt Bertone, North Carolina State University

\section{Hosts}

Puss caterpillars feed on a large variety of plants, but are most commonly found on oaks (Quercus spp.) and elms (Ulmus spp.).

\section{Health Concerns and Symptoms}

Puss caterpillar spines are hollow with a toxin gland at the base. The toxicity of the caterpillar's sting increases with its body size. Spines are found beneath the soft and harmless setae, or hair-like structures. Symptoms from the sting of a puss caterpillar can vary in severity and may include headache, nausea, fever, and seizures. Medical attention is advised if symptoms continue to worsen.

For more information see: http://entnemdept.ufl.edu/ creatures/misc/moths/puss.htm.

\section{Io Moth Caterpillar, Automeris io (Fabricius) (Lepidoptera: Saturniidae) \\ Identificaton}

Io moth caterpillars are pale green with a yellow-white and a red stripe that runs the length of the body (Figure 4). Caterpillars can reach $6.5 \mathrm{~cm}$ in length. Early instars are 
dark brown and molt to a dull orange. The stinging organs are clustered on fleshy protrusions, extending from the body, on the back of the caterpillar. The spines are usually yellow or green with black tips (Figure 4).

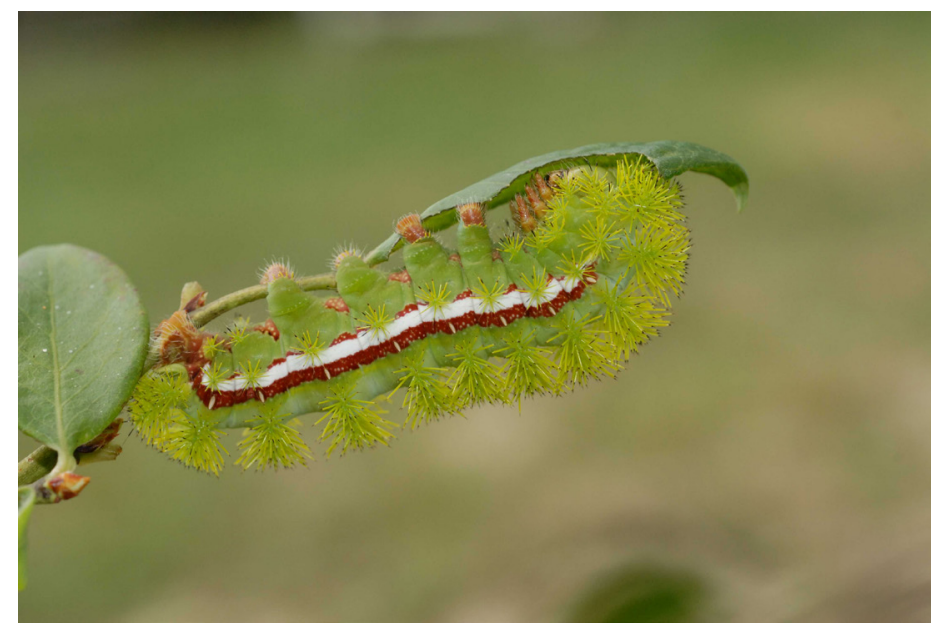

Figure 4. lo moth caterpillar, Automeris io.

Credits: Lyle Buss, UF/IFAS

\section{Hosts}

Io moth caterpillars feed on a large variety of host plants including hibiscus (Hibiscus spp.), elms (Ulmus spp.), maples (Acer spp.), wisteria (Wisteria spp.), and willows (Salix spp.).

\section{Health Concerns and Symptoms}

Io moth caterpillar spines are hollow and can easily break off, embedding deeply into skin. A sudden stinging or burning sensation begins after contact and the affected area may begin to itch and turn red. Pain may begin to decline after a couple of hours, and swelling will decline after about 8 hours. Allergic reactions may occur, and symptoms should be closely monitored.

For more information see: http://entnemdept.ufl.edu/ creatures/misc/io_moth.htm.

\section{Hag Caterpillar, Phobetron pithecium (Smith) (Lepidoptera: Liumacodidae)}

\section{Identification}

Hag moth caterpillars, also called the monkey slug, are light to dark brown. The stinging hairs are on the nine pairs (sometimes fewer) of variable-length, lateral spines. These spines are curved and twisted, likened by some to long, disheveled hair, hence the name (Figure 5).

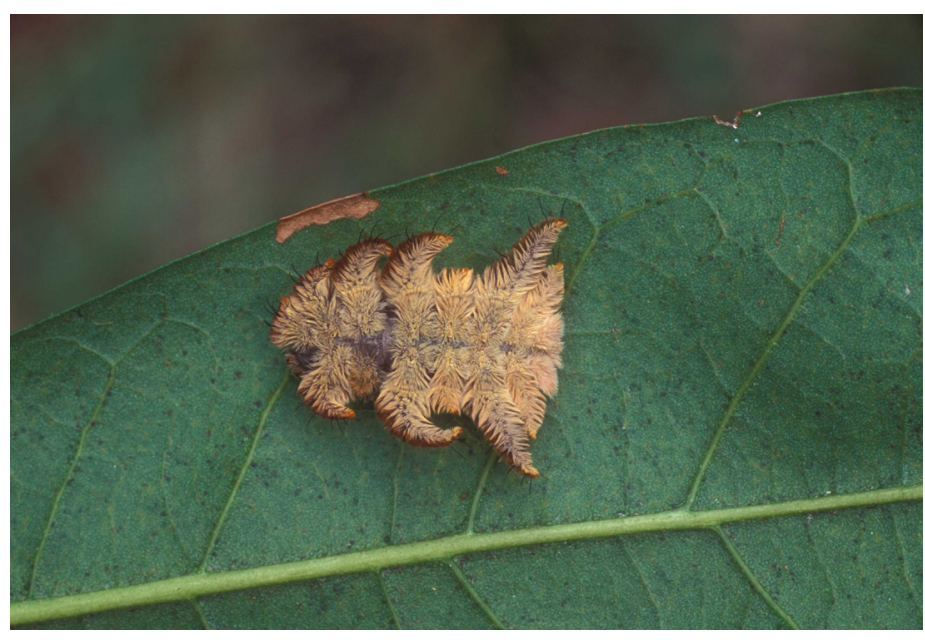

Figure 5. Hag caterpillar, Phobetron pithecium. Credits: Lyle Buss, UF/IFAS

\section{Hosts}

Hag moth caterpillars feed on a variety of woody host plants including oak (Quercus spp.), dogwood (Cornus spp.), and apple (Malus spp.).

\section{Health Concerns and Symptoms}

Hag moth caterpillar spines have toxin glands at their base, and the toxin is released upon contact. Symptoms can vary in severity and include burning or stinging, itching, redness, and inflammation. Allergic reactions are possible but not common. There is conflicting information whether this caterpillar stings or not. Severity can vary for each individual, and caution is advised if handling.

\section{Buck Moth Caterpillar, Hemileuca maia (Drury) (Lepidoptera: Saturniidae) \\ Identification}

Buck moth caterpillars have a dark form and a light form. Both forms have dark, lateral rows of multi-branched urticating spines along their backs (Figure 6). The dark form is more common and is black with many tiny white dots on the body. The light form is white with a reddish head. These are large caterpillars that can reach $6.5 \mathrm{~cm}$ in their final stage.

\section{Hosts}

Host plants include oak (Quercus) and willow (Salix) species.

\section{Health Concerns and Symptoms}

Buck moth caterpillar spines have a toxin gland at the base that is released when spines break off into skin and causes 


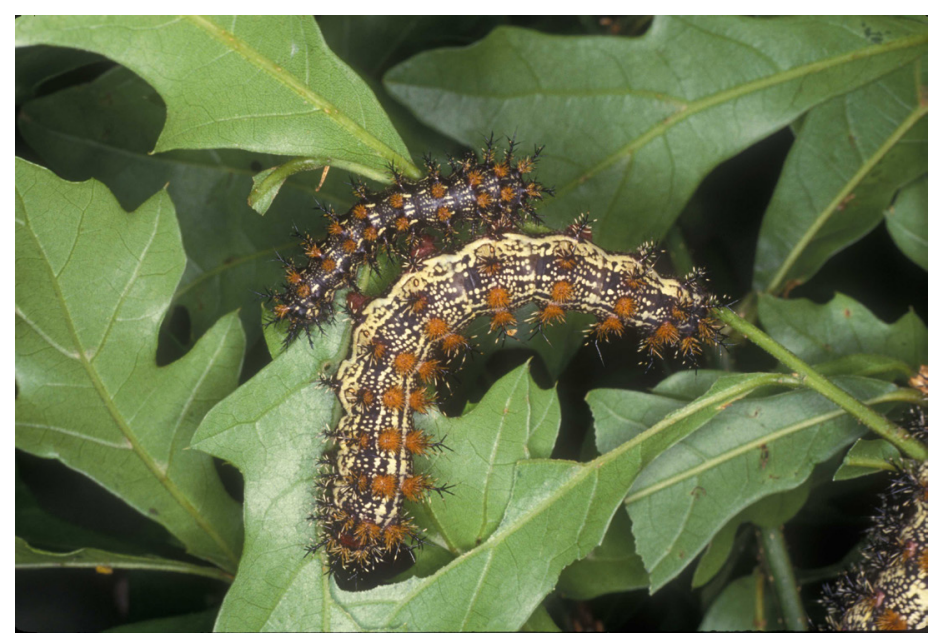

Figure 6. Buck moth caterpillar, Hemileuca maia.

Credits: James Castner, UF/IFAS

sudden stinging, redness, and swelling at the affected area. Symptoms may last from one day to over a week.

For more information see: http://entnemdept.ufl.edu/ creatures/misc/moths/buck_moth.htm.

\section{Spiny Oak-Slug Caterpillar, Euclea delphinii (Boisduval) (Lepidoptera: Limacodidae)}

\section{Identification}

Spiny oak-slug caterpillars have a range of color forms but can be identified by their oval, stout bodies and the abundance of spines protruding from them (Figure 7). This caterpillar has two to four clusters of spines protruding from the rear of its body. It also has clusters of spines that surround the edge of the body. They are approximately 2 $\mathrm{cm}$ long in their final instar.

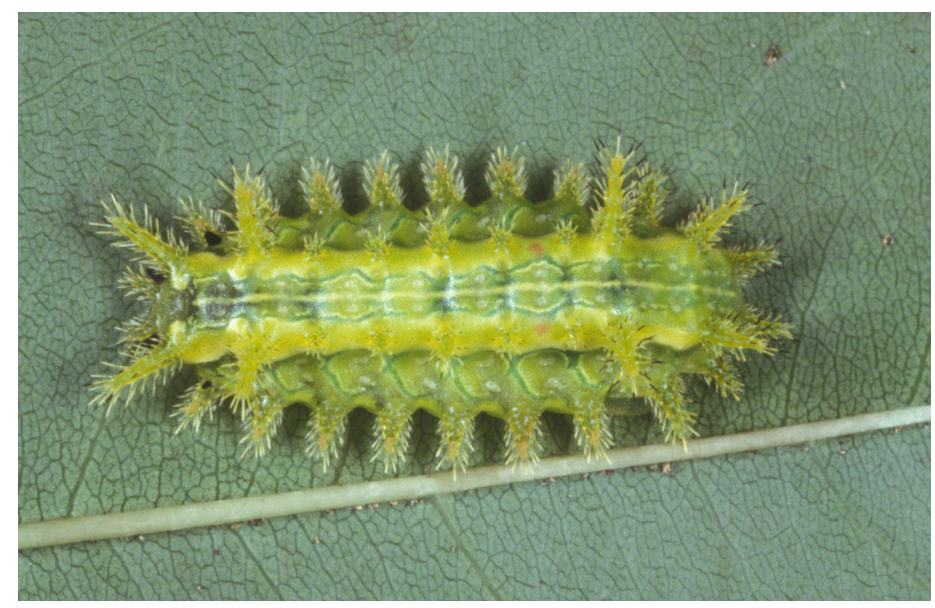

Figure 7. Spiny oak-slug caterpillar, Euclea delphinii.

Credits: Lyle Buss, UF/IFAS

\section{Hosts}

Spiny oak-slug caterpillars feed on a variety of woody plants including oak (Quercus), willow (Salix), and cherry (Prunus) species.

\section{Health Concerns and Symptoms}

Spiny oak-slug caterpillar spines are hollow with a toxin gland at the base. The sting of this caterpillar is milder than that of other stinging caterpillars. Symptoms may include a burning or stinging sensation, redness, and inflammation at the area of contact.

\section{Works Cited}

Bibbs, C. S., and J. H. Frank. 2015. Saddleback caterpillar, Acharia stimulea (Clemens) (Insecta: Lepidoptera: Limacodidae). EENY-522. Gainesville: University of Florida Institute of Food and Agricultural Sciences. http://edis.ifas.ufl.edu/ in923

Hall, D. W. 2012. Puss caterpillar (larva), southern flannel moth (adult), Megalopyge opercularis (Insecta: Lepidoptera: Zygaenoidea: Megalopygidae). EENY-545. Gainesville: University of Florida Institute of Food and Agricultural Sciences. http://edis.ifas.ufl.edu/in976

Hall, D. W. 2014. Io moth, Automeris io (Insecta: Lepidoptera: Saturniidae). EENY-608. Gainesville: University of Florida Institute of Food and Agricultural Sciences. http:// edis.ifas.ufl.edu/in1065

Scott, C., and P. E. Kaufman. 2009. Buck moth, Hemileuca maia (Insecta: Lepidoptera: Saturniidae: Hemileucinae). Gainesville: University of Florida Institute of Food and Agricultural Sciences. http://edis.ifas.ufl.edu/in834 